\title{
Using a Multimodal Education to Develop EFL Pre-service Teachers' Awareness of the Profession
}

Dr. Sara Mohamed Naguib ${ }^{1}$

\begin{abstract}
The purpose of this study was to investigate the effectiveness of using a multimodal education in developing EFL pre-service teachers' awareness of the teaching profession. The sample of the study included 44 pre-service teachers enrolled in the first year, English department for basic education at Port Said Faculty of Education. The instruments of the study included an assessment rubric and an interview presenting both quantitative and qualitative indicators of pre-service teachers' development. The results of the study revealed that multimodal education was effective in developing EFL pre-service teachers' awareness of the teaching profession. This indicates that a multimodality based education can be adopted in the Faculties of Education to achieve various professional purposes.
\end{abstract}

Keywords: multimodal education, EFL pre-service teachers, awareness of the teaching profession, Egypt.

\footnotetext{
${ }^{1}$ Lecturer, Curriculum and Instruction Department, Faculty of Education, Port Said University
} 
مجلة دراسات في المناهج وطرق التتريس، الترقيم الدولي (ISSN 2535-213X)/ العدد 245 (2019م)

استخدام التعليم المتعدد الأساليب فى تنمية الوعي المهنى لمعلمي اللغة الإنجليزية ما قبل الخدمة

هدفت هذه الدراسة إلى التحققى من فاعلية استخدام التعليم المتعدد الأساليب في تتمية الوعي المهنى لمعلمي اللغة الإنجليزية ما قبل الخدمة. شملت عينة الدراسة 44 معلماً قبل الخدمة ملتحقين بالسنة الأولى بقسم اللغة الإنجليزية شعبة التعليم الأساسي بكلية التربية جامعة بورسعيد. تضدنت أدوات

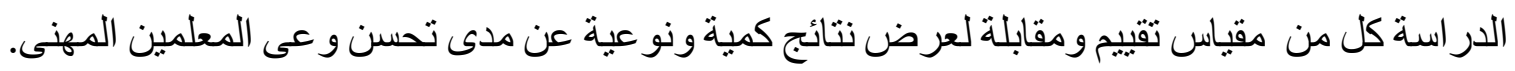
كثفت نتائج الدراسة أن التعليم المتعدد الأساليب كان فعالا في تنمية وعي معلمي اللغة الإنجليزية ما قبل الخدمة بمهنة التدريس. وأوضحت الدر اسة أنه يمكن استخدام هذا النوع من التعليم في كليات التربية لتحقيق أغر اض مهنية وتربوية مختلفة.

الكلمات المفتاحية: التعليم المتعدد الأساليب ، معلمى اللغة الإنجليزية ما قبل الخدمة ، الوعى المهنى بمهنة التنريس، مصر. 
مجلة دراسات في المناهج وطرق التّريس، الترقيم الدولي (ISSN 2535-213X)/ العدد 245 (2019م)

\section{Using a Multimodal Education to Develop EFL Pre-service Teachers' Awareness of the Profession}

\section{Introduction}

Language teacher education is "the sum of experiences and activities through which individuals learn to be language teachers" (Freeman, 2001, p.72). In Egypt, EFL Pre-service teachers' education at Faculties of Education should guarantee that they develop all the skills required to become professional teachers. To achieve this, their education should include all kinds of experiences to develop professionally as well as academically.

Concerning professional experience, it is provided for pre-service teachers in the form of methodological courses and practicum. The methodological courses in the preparation program are presented to preservice teachers from the first year to the fourth year in a gradual way starting by introducing the basic teaching skills any teacher must have to more complicated methodological issues. This helps the Faculty recently joined students to form a cognitive background about the teaching career.

As for Practicum, it is described as Lucero (2016, p.144) mentioned as an event that brings to life the feelings, beliefs, and background experiences of pre-service teachers about teaching a language and the fact of being a teacher. Practicum helps in raising pre-service teachers' awareness about the teaching career as it is the first contact with actual classroom.

However, various challenges were recorded regarding professional preparation as many researchers such as Hamad (1999); Mostafa (1999; 
2005); Hamadtoh (2007); Abdel-Halim (2008); and El-Bassuony (2011) agreed. Concerning methodological courses, some of the problems were: lack of prior knowledge about teacher's expected roles, low motivation to attend and participate, considering academic courses more important, and inability to visualize the situation in which the theoretical parts in concern will be practiced.

Similarly, various challenges were recorded in early practicum practice. The most difficult challenge was how to reach an adequate level of professional awareness and bridge the gap between theory and practice. Many researchers, such as Hamadtoh (2007); Badawi (2009); and El-Bassuony (2011) indicated that professional awareness should be adequately established earlier. In other words, if pre-service teachers have early professional awareness, they are expected to easily bridge the gap between theory and practice and perform better even in the beginning of practicum.

Professional awareness of pre-service teachers according to Borg (2001); Russell, Bebell, O’Dwyer and O’Connor (2003); Andrew (2007); Mills (2010); Wang $(2012 ; 2015)$ refers to raising their awareness about the teaching career and their knowledge in the areas of language, pedagogy, culture and technology. A review of teacher cognition theories suggests the importance of teacher awareness development. Moreover, as CastanedaTrujillo and Aguirre-Hernández (2018, p. 159) confirm pre-service teachers' awareness should receive more focus as the courses they study have not been designed for having them become aware of the educational realities they will face in their careers. 
Thus, one of the first steps to raise pre-service teachers' awareness is to develop methodological courses and enrich them with actual teaching experience such as monitoring those directly involved in the teaching process and learning from real classroom experience. In an attempt to provide this kind of experience to pre-service teachers, the researcher followed the multimodality theory and designed a multimodal education to be used in teaching one methodological course that targets professional preparation of pre-service teachers.

Multimodality is described as an interdisciplinary approach drawn with an emphasis on communication and representation (Jewitt, 2013, p.250). The essence of multimodality therefore, according to Papageorgiou and Lameras (2017, p.133), is to provide different types of resources to the student for stimulating learning in meaningful ways within and across disciplines.

Currently, multimodal education gained significant importance worldwide as it uses a teaching mode that combines independent study with computer and multimedia classroom teaching supported by network technology. The constantly increased media in the classroom makes education present a multimodality trend (Wang, 2015, p.473). Thus, following a multimodal education confirms that Information transfer mode includes multiple modes.

In the present study, the researcher designed a multimodal education model based on network resources, handouts, and class discussion in order to provide pre-service teachers with a professional experience that is expected to raise their awareness about the teaching career. 
مجلة دراسات في المناهج وطرق التّريس، الترقيم الدولي (ISSN 2535-213X)/ العدد 245 (2019م)

\subsection{Context of the Problem}

First year pre-service teachers who recently joined Faculty of Education lack awareness of the teaching profession concerning the roles expected to be performed from teachers, the problems they may face, and professional ways to overcome expected classroom problems. They are not aware yet that to be competent teachers, they need more than academic preparation. They pay much attention to academic courses, still considering teaching skills and classroom issues unnecessary or might be postponed. Moreover, they lack motivation to learn about their future career especially through the traditional course lectures.

The problem was noticed by the researcher while teaching one methodological course to first year EFL pre-service teachers. Actually the researcher taught the same course content to first year pre-service teachers in previous years and the results were not satisfying in relation to their motivation, participation, and achievement which motivated the researcher to investigate the use of a new treatment that is considered, according to many researchers such as Jewitt (2013); Wang (2015); and Lameras (2017), an educational trend especially with the presence of technology that appeals to the sample in concern.

Moreover, reviewing previous literature regarding professional preparation confirmed a problem in various aspects. Many previous studies, such as Hamad (1999); Mostafa (1999; 2005); Hamadtoh (2007); AbdelHalim (2008); Badawi (2009); El-Bassuony (2011); and Diab, Abdel-haq, and 
Aly (2018) shed the light on the importance of developing professional preparation of pre-service teachers due to the recorded challenges faced .

Furthermore, the researcher conducted a pilot study on a sample of firstyear English department students in which they were questioned about the roles they expect to perform as language teachers and the problems they consider challenging in the class setting. Their responses reflected low level of awareness.

Thus, the present study aims at presenting an early interesting professional education that narrows the gap between theory and practice and widens EFL pre-service teachers' perceptions about their future career. By drawing their attention to real classroom problems shedding the light on ways to solve them and teachers' roles that must be fulfilled, pre-service teachers become aware of their future career and start their professional preparation effectively.

\section{Statement of the Problem}

The problem of the study thus can be identified as follows: EFL preservice teachers lack awareness of the teaching profession. They are unable to perceive the requirements of their future career which affects their concentration as well as motivation. Hence, this study sought to find answers to the following questions:

1- What are the main aspects of professional awareness?

2- What are the main features of a multimodality based education? 
مجلة دراسات في المناهج وطرق التّريس، الترقيم الدولي (ISSN 2535-213X)/ العدد 245 (2019م)

3- How far is a multimodal education effective in developing EFL preservice teachers' awareness of the teaching profession?

\subsection{Purpose of the Study}

The purpose of the study was twofold:

1- Investigating EFL pre-service teachers' awareness of the roles teachers must fulfill inside the classroom.

2- Determining the effect of using multimodal education on developing EFL pre-service teachers' awareness of the teaching profession.

\subsection{Significance of the Study}

The significance of the study stems from the following considerations:

- The treatment and the instruments presented in the study might be beneficial to EFL researchers and course designers.

- The study might provide guidelines upon which further treatments may be designed to develop EFL pre-service teachers' professionalism.

- EFL pre-service teachers might use the multimodality based treatment to develop various skills.

\subsection{Delimitations of the Study}

This study was restricted to:

- A multimodal education based on combining network resources, handouts, and class discussion. 
- Two techniques of Investigating EFL pre-service teachers' awareness of the profession; i.e., the assessment rubric and the interview.

- A sample of first year English department students for basic education at Port Said Faculty of Education.

- A limited duration for implementing the treatment (eight weeks).

\subsection{Definition of Terms}

\section{Multimodal Education}

Multimodal Education refers to using multiple modes of representation in the classroom, combining elements of print, visual images and design (Jewitt, 2008, p.242).

According to Wang (2015, p.473), Multimodality in education is also called as multi-symbol, including spoken language, written language, image, diagrams, space and various kinds of symbol resources used to construct meanings.

In the present study, multimodal education is defined as teaching a methodology course to pre-service teachers at Port Said Faculty of Education using network resources, handouts, and class discussion in order to provide a professional experience that raises awareness about the teaching profession.

\section{Awareness of the Profession (Professional Awareness)}

Borg (2003, p.85) describes teachers' professional awareness as what shapes teachers' practices in classroom contexts, which is affected by what teachers accumulated in teacher education contexts where their own experiences as learners link to their beliefs. 
According to Wang (2015, p. 5), teacher's awareness refers to teachers' general knowledge about any aspect of a language, culture, or technology.

In the present study, professional awareness is defined as appropriate knowledge first year pre-service teachers should have about the teaching profession and the roles they have to fulfill in the EFL classroom.

\section{Review of Literature}

In the following lines the researcher sheds more light on the concepts of multimodal education and awareness of the teaching profession.

\subsection{Multimodal Education The Multimodality Trend}

A modality is a way of representing information in some medium. Multimodality includes at least two different modalities; it allows an integrated use of various forms of interaction. The concept of multimodality is gaining significant importance as a demonstrating setting in education and a research trend among researchers. Currently, information transfer mode is no longer confined to a single text. Instead, it includes multiple modes such as audio frequency, video and three-dimensional animation. According to Wang (2015, p. 473), the constantly increased media in the classroom makes education present a multimodality trend.

Multimodality in today's classrooms refers to 'multiple' modes of representation, with combined elements of print, visual images and design (Jewitt, 2008, p.249). Multiple modes of representation include capabilities of combinations of oral and written language, visual, gestural, tactile and spatial 
representations (Cope and Kalantzis, 2009). The following figure is a visual representation of the concept of multimodality:

Figure1. Multimodal Learning

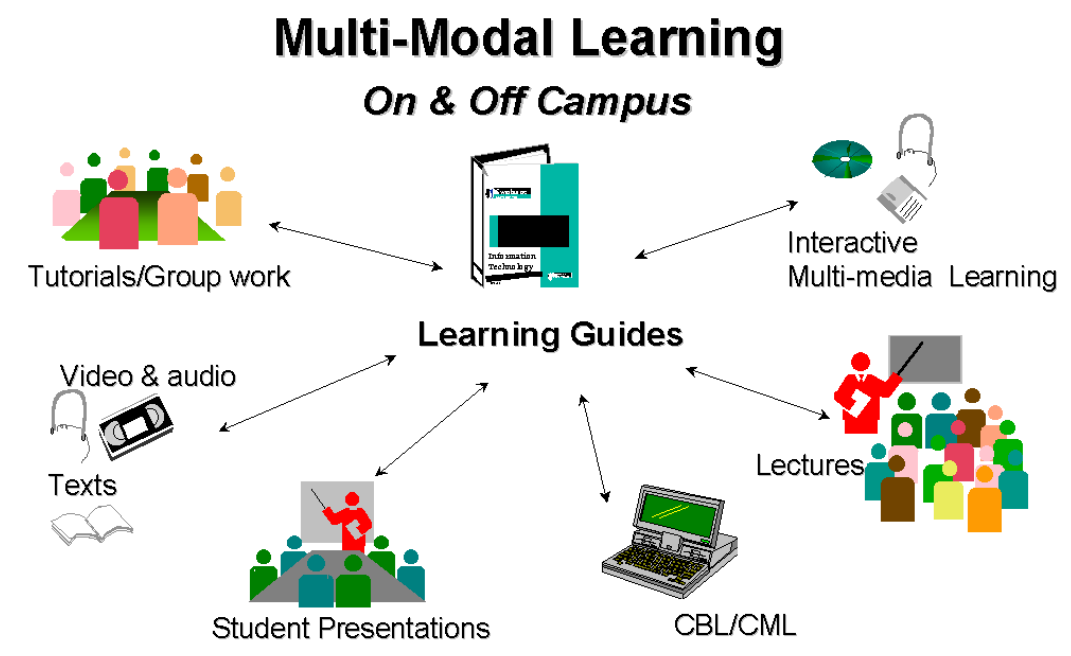

(Source: Salkovic, 2013, p.1)

Clearly, there is a transitional shift from print-based education to multimodal education, as using only the traditional printed data do not achieve the required educational purposes. In this concern, Mayer (2001) argues that student's learning becomes more meaningful when an array of interactive tools and resources are deployed rather than using text alone. Moreover, the visual representation of content is vital for communicating subject matter and improving students' understanding.

\section{The Relation between Multimodality and Multimedia}

Multimodality, also called multi-symbol, has a significant relation with multimedia. Multimodality as well as multimedia includes spoken language, 
written language, image, diagrams, and various kinds of symbol resources used to construct meanings. However, multimodality has an extended dimension as it includes on line assisted technology and several communication forms. The multimodal class uses multimedia, various forms of computer assisted technology, language, performances, and other forms of communication to convey meaning in a more comprehensive way.

According to Kress and van Leeuwen (2001) and Sharples (2016), who studied the relationship between modality and media, multimedia resources and tools in a multimodal environment may include interactive videos and images, recorded lecture presentations, online quizzes, discussion forums (synchronous and asynchronous), visual representations of student data.

\section{Previous Research on Multimodality}

Research has reported on interventions, case studies, conceptual frameworks and design of teaching and learning activities using multimodal technologies (Cope and Kalantzis, 2009). As for the language teaching classrooms, New London Group (1996) was the first to apply multimodality on language teaching as they thought the training of the students' multiliteracy was the main task of language teaching which can be effectively achieved in a multimodal class. From then on, the researches concerning multimodality and language teaching began to prevail. Following are some of the research conducted using multimodality for different educational purposes:

In the study of Ajayi (2008), it was found that 33 ELLs in ninth to eleventh grade enrolled in the advanced ESL program attained metacognition 
and metalinguistic skills and demonstrated their subjectivity as "active designers of meaning" and "productive citizens" as they explored multiple learning activities engaging multimodal resources that provided different semiotic possibilities for meaning making and communication. In another research with 18 seventh-grade ELLs, Ajayi (2009) corroborated the earlier finding in that multimodal texts assisted the learners in using different types of resources and finding "multidirectional paths" toward composing which also fostered critical thinking skills.

Guichon and McLornan (2008) aimed at studying the effects of multimodality on second language learners. They put forward the curriculum design principles and ways to apply computer assisted teaching for the purpose of helping learners improve in learning the target language.

Kim (2010) conducted a qualitative case study that studied classroom interaction in an adolescent English as a second language classroom. The researcher explored the nature of effective teaching practices with emphasis on their influence on English Language Learners' language and identity development. Developmental analyses of prolonged class observations, semistructured interviews with the teacher and students, and documents led to finding that Transformative Multimodal Practices (TMP) in action in the shared, socio educational space of intensive learning may play an important role on the development of ELLs' academic literacies and identities. Suggestions for transformative pedagogies in the times of diversity and networked multimodality, and issues for raising awareness of teachers, teacher educators, administrators, and policy makers were also discussed. 
Wang (2015) presented a paper that analyzed the current status of college English teaching and the existing problems, elaborates the research trends of the theory of multimodal discourse analysis. The researcher aimed to explore the question as how to construct college English teaching model from the perspective of multimodal discourse. The researcher confirmed that under the multimodality-based college English teaching model, teachers should concentrate on cultivating students' multi-literacy, coordinating different modalities, to achieve the teaching objectives.

Papageorgiou and Lameras (2017) aimed at reporting on teachers' experiences of multimodality in teaching and learning. They used a smallscale online survey with closed and semi-structured questions which was deployed to school and university teachers $(n=68)$ for eliciting their experiences in multimodal teaching and learning. Thematic analysis has been adopted as the overarching methodology for reporting patterns in the data from the survey.

\subsection{Awareness of the Teaching Profession The Path of Professional Awareness}

It is very important to identify the path of professional awareness since this awareness is what shapes the identity of the teacher. Basically, there is a formal path of professional awareness based on three major indicators: resources, experiences and beliefs (Bransford, Brown and Cocking, 2000; Borg, 2003; Phipps and Borg, 2009). 
As a direct learning process, awareness can occur through the direct input of knowledge from resources such as textbooks, workshops, formal education, degree programs, graduate programs on teaching ELLs, and the experiences of teaching ELLs. However, teachers also learn from informal experiences such as community activities and extracurricular school activities in which teachers share knowledge with other teachers and ELL students' parents (Bransford, Brown and Cocking, 2000; Egbert and Salsbury, 2009).

There is another virtual factor that impact awareness which is the teacher's beliefs. According to Andrews (2007) and Borg (2009), teacher awareness development is influenced by teachers' beliefs which further shape teachers' instructional decisions (Phipps and Borg, 2009).

Considering professional awareness of pre-service teachers in particular requires reflection on teacher preparation program. In this respect, Kaymakamoğlu (2019, p.1001) confirms that the role of the teacher trainer cannot be disregarded since it is one of the responsibilities of him/her to create learning environments in which the pre-service EFL teachers can cognitively, affectively and intellectually grow. To obtain this, there is a need to support the pre-service EFL teacher's experience of learning and teaching in order to gain practical knowledge besides theoretical knowledge. With the help of this experience, learners can start to construct new understandings and meanings which can result in some sort of awareness. 
Paying enough attention to the aforementioned sources of professional awareness, can help curricula designers prepare competent awareness development programs for both pre-service and in-service teachers because teacher awareness might be a result of what teacher education contexts provide (Borg, 2003).

\section{The Relation between Awareness and Professional Development}

According to Sherman (2014, p.18) to achieve professional development in any career, the individual goes through three processes and the first one is always career/professional awareness as the following figure represents:

Figure2. Processes of Career Development

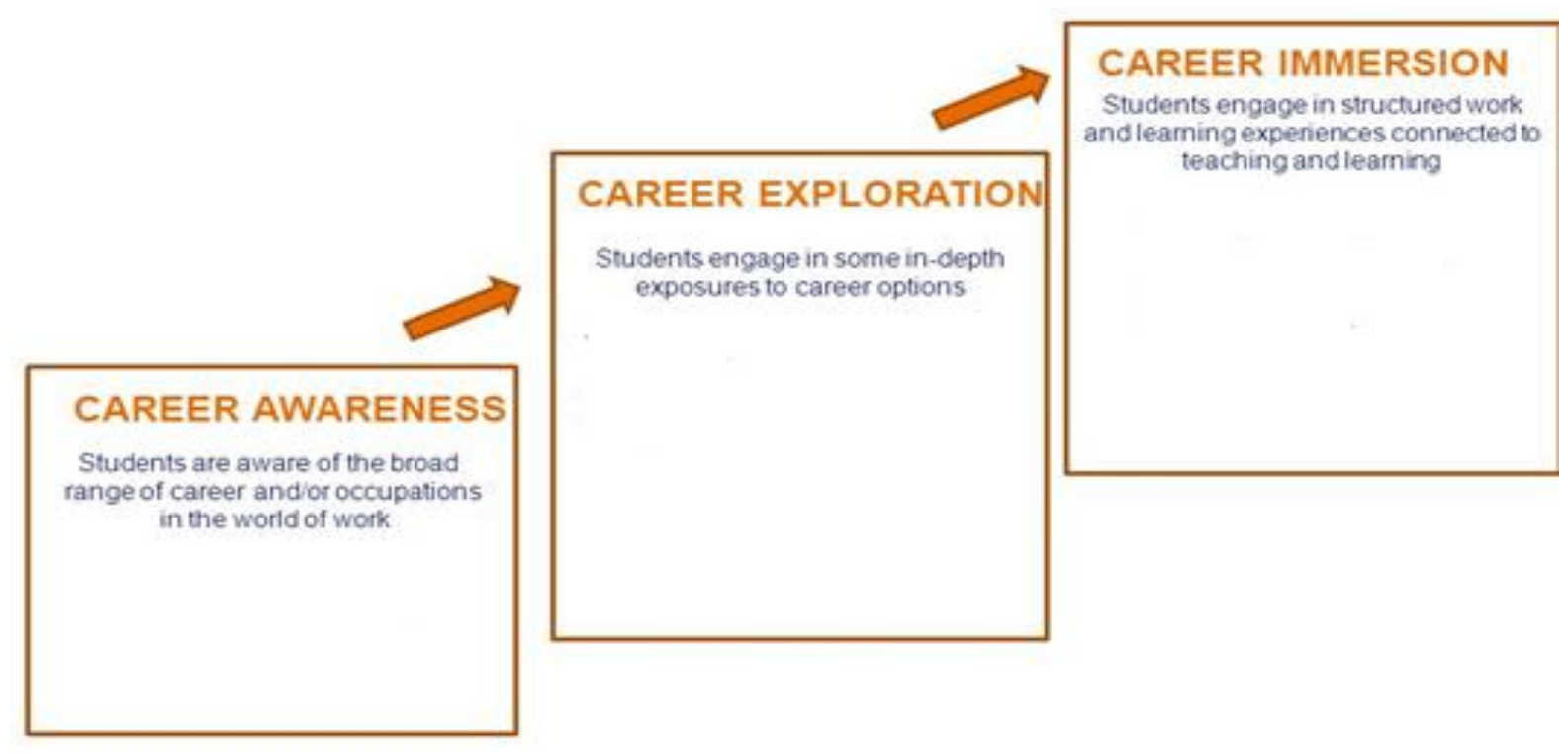

(Source: Sherman, 2014, p.18) 
Similarly, according to Kumaravadivelu (2006, p. 173), professional awareness is the beginning of professional development. Still, there is a reciprocal connection between the two as there is an emphasis on "theorizing from practice and practicing the theorized".

Awareness, as the point of start for teachers' professional development, includes knowledge of teacher's expected roles. This Standard of Knowledge is the core of many professional preparation programs. According to OECD/UNESCO (2016, p.199), these standards require pre-service teachers to have knowledge of typical foundation and pedagogical topics like curriculum development, educational measurement and evaluation, classroom management and practicum. From the perspective of OECD-UNESCO, preservice programs cover the three broad content areas typical of teacher preparation courses (foundation, pedagogy and subject matter).

\section{Previous Research on Pre-service Teachers' Professional Awareness}

The study of Badawi (2009) concentrated on professional knowledge and performance of EFL prospective teachers. The basic objective in this study was to investigate the effectiveness of using blended learning model in developing EFL prospective teachers' pedagogical knowledge and performance. The study sample included (38) EFL Saudi prospective teachers (fourth-year students) at the Faculty of Education and Arts, University of Tabuk, KSA. To collect the data required, a blended TEFL course, a pedagogical knowledge test, and a pedagogical performance scale were designed and implemented. During the first term of the academic year 20082009, the participants were divided into two equal groups in terms of their 
number, accumulative grade point, and pedagogical knowledge. The first group studied four TEFL units using the traditional face-to-face model, while the second group studied the same four units using the suggested blended learning model. Results of the pedagogical knowledge test revealed that the mean scores of the EFL prospective teachers in the blended group surpassed the mean scores of those who were in the traditional face-to-face group. In addition, there were no significant differences between the two groups in terms of their mean scores on the pedagogical performance scale.

El-Bassuony (2011) concentrated in her study on the professionalism, a complex construct that includes numerous components such as commitment and efficacy, of EFL pre-service teachers. The purpose of the study was to investigate the effectiveness of a treatment based on collaborative action research and facebook in developing EFL pre-service teachers' perception of professionalism. The sample of the study included (18) pre-service teachers enrolled in the fourth year, English department for basic education at Port Said Faculty of Education. A mixed methods research design was adopted for this study to allow triangulation of data and explore the multi-dimensional nature of teacher professionalism. The instruments of the study included an interview guide based on STEPS standards and a collaborative action research rubric. The results of the study revealed that the treatment was effective in developing EFL pre-service teachers' perception of professionalism. Pre-service teachers started with a limited perception of a professional teacher and moved to a clear, organized, and complicated one as shown in their concept maps and answers to interview questions. On the other hand, they stressed the importance of collaborative action research and facebook in helping them to 
solve different teaching problems and realize the varied aspects of professionalism.

Wang (2012) conducted a pilot study on pre-service teachers to answer the question "can practicing foreign language learning online help teachers transfer linguistic, cultural, and technological awareness into teaching English language learners?" He mentioned that pre-service teachers perceived that their initial experiences as online language learners increased their linguistic, cultural and technological awareness, which would further benefit them when working with diverse students. However, that study was unclear about whether teachers perceived that they could transfer their awareness into teaching practice. Therefore, extending the pilot study, a follow-up study explored in-service teachers' perceptions of linguistic, cultural and technological awareness transfer in teaching English Language Learners by asking them to engage with an online language course and reflect on their experience. This study proposes a model for language teacher linguistic, cultural and technological awareness development and transfer, as well as discusses issues related to language teacher awareness transfer.

As for the study of Diab , Abdel-Haq , and Aly (2018), it aimed at investigating the effectiveness of using the CLIL approach to enhance EFL student teachers' cultural awareness. The study followed the experimental one-group design. The participants were 38 third year students enrolled in English Language section, Faculty of Education, Benha University. To identify the most important and required EFL cultural awareness dimensions for the participants, a checklist of EFL cultural awareness was developed and 
validated by a number of EFL jury members. A pre-post EFL cultural awareness test was developed. Students were pre-tested, to determine their entry level of EFL cultural awareness. Then, they were trained through the suggested CLIL-based program on how to develop their cultural awareness dimensions (knowledge and situations) and trained adequately through its main four phases: processing the text, identification and organization of knowledge, language identification and tasks for students). The test was readministered on the participants to assess the progress in their level of performance in EFL cultural awareness. Findings of the study revealed that there was a statistically significant difference at 0.01 in the pre-post assessment of EFL cultural awareness in favour of the post-assessment.

Çakıcı (2018) conducted a study that investigated the possible relationship between Metacognitive Awareness (MA) and Critical Thinking Skills (CTS) in a foreign language learning context. In addition, this research aimed to probe the effect of gender and years of pre-service English language teachers on the relation between metacognitive awareness and critical thinking abilities. 218 pre-service EFL (English as a Foreign Language) teachers participated in the study. Metacognitive Awareness Inventory and Critical Thinking Questionnaire were employed to gather necessary data. Obtained results confirmed that there existed a highly significant positive correlation between MA and CTS. Besides, the results indicated that there was a strong relation between the years of pre-service EFL teachers and their MA and CTS. Seniors were found to be more metacognitively aware and critical thinkers than their counterparts. Conversely, it was revealed that there was no gender effect on both MA and CTS. Finally, certain suggestions were set for 
tertiary institutions to develop metacognition and critical thinking skills in foreign language classroom settings.

In the study of Kaymakamoğlu (2019), the aim was to explore the ways of helping pre-service EFL teachers gain and develop practical theories related to teaching EFL. For this purpose, the researcher devised a model primarily based on creating awareness on pre-service EFL teachers related to basic methodological knowledge. The model aimed to support the pre-service EFL teachers' practical knowledge construction by creating micro-teaching sessions in which they could put their theoretical knowledge into practice. The data were collected during 13 weeks in which every pre-service EFL teacher found 50 minute four micro-teaching session opportunities: two microteaching sessions for teaching reading and two micro-teaching sessions for teaching listening. 28 pre-service EFL teachers were the participants of the study. The data were collected from pre-service EFL teachers' self-evaluation reports, peer evaluation rubrics, lesson plans and teacher evaluation documents in each micro-teaching sessions in order to see the development if there was any during 13 weeks. At the end of the process, the student teachers were also asked to express their views about the process of learning and it was found that the proposed model created awareness in them about the difference between theoretical knowledge and practical knowledge.

Clearly, pre-service teachers' professional awareness received attention from many researchers who adopted a variety of treatments as introduced. Also, most of these studies focused on third or fourth year in the preparation program. Still, in the present study establishing an early professional 
awareness was the main focus with administering a new treatment based on multimodality that proved successful for many educational purposes.

\section{Methodology}

\subsection{Design of the Study}

The researcher used a mixed methods research design combining both quantitative and qualitative techniques. The assessment rubric presented quantitative data and the interview presented qualitative one. All responses were analyzed to determine the development in EFL pre-service teachers' awareness after the suggested multimodality-based treatment.

\subsection{Participants}

The participants in this study included 44 pre-service teachers, 38 females and 6 males. They were enrolled in the first year, English department for basic education at Port Said Faculty of Education, Port Said University. The study took place in the second term of the academic year 2018-2019 while the researcher was teaching the participants the methodological course "Curriculum Teaching 1."

\subsection{Instruments of the Study}

Two instruments were used in this study to determine the effect of using multimodal education on developing EFL pre-service teachers' awareness of the teaching profession:

A-An Assessment rubric of the reports required from EFL pre-service teachers that reflect their awareness of the profession. 
مجلة دراسات في المناهج وطرق التّريس، الترقيم الدولي (ISSN 2535-213X)/ العدد 245 (2019م)

B-An interview with EFL pre-service teachers regarding their perception of teachers' roles.

A- The Reports Assessment rubric

To determine the effect of using multimodal education on developing EFL pre-service teachers' awareness of the teaching profession, the participants were asked to write two comprehensive reports at the beginning and after the treatment. An assessment rubric was used to evaluate participants' performance and investigate any progress in their perception of teaching. The rubric was a 4-point scale in which (4) means distinguished, (3) means proficient, (2) means basic, and (1) means unsatisfactory. (For more details see Appendix A).

Before using the rubric, it was presented to a panel of jury of specialists in English curriculum and instruction (N.3) and their comments were taken into consideration.

\section{B- The Interview}

The interview aimed at eliciting pre-service teachers' points of view about teaching. Their responses reflected their awareness of the profession. Pre-teachers are asked about three main topics: the roles of the teacher inside the classroom, the challenges they expect to find while practicing teaching, and ways of overcoming expected problems from their points of view. The interview consists of six questions, two questions for each topic. Before applying this instrument, it was presented to a panel of jury of specialists in English curriculum and instruction (N.3) and their comments were taken into consideration. All the study participants were interviewed and all interviews 
were recorded. The participants' responses were analyzed, qualitatively, to investigate their awareness of the teaching profession. (For more details see Appendix B).

\subsection{The Treatment}

The treatment in the present study is based on the theory of multimodality. The researcher designed and applied a multimodal education based on combining network resources, handouts, and class discussion. The treatment consisted of eight sessions. Each session took one hour weekly over a period of two months. It was applied in the second term of the academic year 2018-2019.

In each session of the treatment, pre-service teachers were introduced some prominent issues related to the teaching profession such as the roles teachers must fulfill in the classroom, the challenges they face, and ways to overcome difficulties. The presentation of these topics was done combining network resources, handouts, and class discussion to provide an interesting contemporary setting convenient to various learning styles.

Thus, the general steps followed in each session were:

- Presenting an appropriate warm-up.

- Introducing a theoretical background about the topic.

- Presenting handouts containing written language, various educational figures, and interactive questions/activities.

- Discussing the authentic videos the students were required to download and watch. 
(Internet sites of the videos were announced in session one, containing English teachers modeling and documenting their teaching performance inside the EFL classroom. The videos were direct representation of the theoretical knowledge presented in the session.)

- Recording comments and personal notes.

Moreover, there was an additional step after the first session and the last session. Participants were asked to write two reports, one after the first session and the other after the last session to compare the change in their awareness and perception of the teaching profession. (For more details about the treatment see Appendix C).

The following figure summarizes the content topics covered and the steps followed in each session during the multimodal education application:

Table 1. Multimodal Education Steps and Topics

\begin{tabular}{|l|l|l|l|}
\hline $\begin{array}{l}\text { Session } \\
\text { Number }\end{array}$ & Topic & $\begin{array}{l}\text { General } \\
\text { Steps }\end{array}$ & Additional Steps \\
\hline $\begin{array}{l}\text { Session } \\
\text { One }\end{array}$ & $\begin{array}{l}\text { Introduction } \\
\text { to the course }\end{array}$ & $\begin{array}{l}\text {-Presenting } \\
\text { warm-up. }\end{array}$ & $\begin{array}{l}\text {-Introduction to steps followed } \\
\text { during the course (based on } \\
\text { multimodality.) } \\
\text {-distributing internet sites list. }\end{array}$ \\
\cline { 1 - 1 } $\begin{array}{l}\text { Session } \\
\text { Two }\end{array}$ & $\begin{array}{l}\text { Learning } \\
\text { theoretical } \\
\text { Objectives }\end{array}$ & $\begin{array}{l}\text {-Presenting } \\
\text {-Giving an assignment of writing } \\
\text { handouts. } \\
\text { a report about perception of the } \\
\text { teaching profession. }\end{array}$ & \\
\hline
\end{tabular}


مجلة دراسات في المناهج وطرق التتريس، الترقيم الدولي (ISSN 2535-213X)/ العدد 245 (2019م)

\begin{tabular}{|c|c|c|c|}
\hline $\begin{array}{l}\text { Session } \\
\text { Number }\end{array}$ & Topic & $\begin{array}{l}\text { General } \\
\text { Steps }\end{array}$ & Additional Steps \\
\hline $\begin{array}{l}\text { Session } \\
\text { Three }\end{array}$ & $\begin{array}{l}\text { Applying } \\
\text { Teaching } \\
\text { Methods }\end{array}$ & \multirow{7}{*}{$\begin{array}{l}\text {-Discussing } \\
\text { authentic } \\
\text { videos. } \\
\text {-Recording } \\
\text { comments } \\
\text { and } \\
\text { personal } \\
\text { notes. }\end{array}$} & \\
\hline & & & \\
\hline $\begin{array}{l}\text { Session } \\
\text { Four }\end{array}$ & $\begin{array}{l}\text { Using } \\
\text { Teaching } \\
\text { Aids }\end{array}$ & & \\
\hline $\begin{array}{l}\text { Session } \\
\text { Five }\end{array}$ & $\begin{array}{l}\text { Using Warm- } \\
\text { up }\end{array}$ & & \\
\hline $\begin{array}{l}\text { Session } \\
\text { Six }\end{array}$ & $\begin{array}{l}\text {-Closure } \\
\text { Techniques } \\
\text {-Board } \\
\text { Organization }\end{array}$ & & \\
\hline $\begin{array}{l}\text { Session } \\
\text { seven }\end{array}$ & $\begin{array}{l}\text { Questioning } \\
\text { Skills }\end{array}$ & & \\
\hline $\begin{array}{l}\text { Session } \\
\text { Eight }\end{array}$ & $\begin{array}{l}\text { Classroom } \\
\text { Management }\end{array}$ & & $\begin{array}{l}\text {-Giving an assignment of writing } \\
\text { a report about perception of the } \\
\text { teaching profession. } \\
\text {-Assigning an appointment for } \\
\text { an extended oral discussion. } \\
\text { (To Elicit responses for } \\
\text { interview questions.) }\end{array}$ \\
\hline
\end{tabular}

\section{Results and Discussion}

\subsection{Results}

The results of the study will be presented in terms of the quantitative and the qualitative indicators of development in the awareness of pre-service teachers regarding the teaching profession. The quantitative indicators are related to the assessment rubric results while the qualitative indicators are represented by the interview results. 


\subsubsection{Results of Assessment Rubric}

Each of the participants in this study wrote two reports, one at session one and the other at session eight; the topic of the report was: "The roles teachers must perform in the EFL class". Thus, there were two sets of reports: set one $(n=44)$ written at the beginning of the treatment and set two $(n=44)$ after the treatment. In order to evaluate the reports $(n=88)$, the researcher prepared, validated, and administered the assessment rubric. There were four main assessment categories in the rubric: correctness of themes, comprehensiveness of content, considering specialization, and personal views.

The researcher used paired samples t-test in order to compare the pretreatment and post-treatment assessment results and determine the relative extent of change achieved by implementing the treatment. As table 2 shows, it was found out that there were statistically significant differences at 0.0001 level between the means of the total scores of the participants in the pretreatment assessment and their total scores in the post-treatment assessment.

Table2. T-test results comparing the means of participants $(n=44)$ in the pretreatment assessment and the post-treatment assessment.

\begin{tabular}{|l|l|l|l|c|}
\hline \multicolumn{2}{|c|}{ M } & \multicolumn{1}{c|}{ SD } & DF & t-value \\
\hline Pre & 6.09 & 1.22 & 43 & 32.2432 \\
\cline { 1 - 3 } Post & 11.32 & 1.70 & & \\
\hline
\end{tabular}

*Significant at 0.0001

As indicated in Table (2) above, the Paired t-test results were: concerning $\mathrm{P}$ value and statistical significance, the two-tailed $\mathrm{P}$ value was less 
than 0.0001. According to conventional criteria, this difference was considered to be statistically significant.

The obtained $t$ value was 32.2432 , a significant value at the level of 0.0001 , indicating the significant influence of the multimodal education based treatment on developing pre-service teachers' professional awareness.

Apparently, there is a significant increase in the score participants achieved regarding the two reports. This indicates that participants gained knowledge and awareness about the teaching profession due to the administration of the suggested treatment.

\subsubsection{Results of the Interviews}

The researcher performed an interview with all the participants $(n=44)$ after session eight. Pre-service teachers' responses to the interview questions revealed the change in their perception of teaching and consequently, in their awareness of the teaching profession. The interview questions aroused three main topics and for each topic participants answered two questions. The main themes involved in the participants' responses, after the researcher's summary of similar ideas to avoid redundancy, are as follows:

Table3. Participants' Main Themes

\begin{tabular}{|c|c|c|}
\hline $\mathbf{N}$. & Topic & \begin{tabular}{|l|} 
Participants' Responses \\
\end{tabular} \\
\hline One & Teacher's Roles & $\begin{array}{l}\text {-The roles teachers should perform are: } \\
\text { - Conveying the new information in the } \\
\text { lesson. } \\
\text { - Managing the classroom. } \\
\text { - Monitoring students' understanding. } \\
\text { - Encouraging weak students. } \\
\text { - Motivating students. }\end{array}$ \\
\hline
\end{tabular}


مجلة دراسات في المناهج وطرق التّريس، الترقيم الدولي (ISSN 2535-213X)/ العدد 245 (2019م)

\begin{tabular}{|c|c|c|}
\hline $\mathbf{N}$. & Topic & Participants' Responses \\
\hline & & $\begin{array}{l}\text { - Evaluating the students. } \\
\text {-Teaching skills that teachers should master are: } \\
\text { - Forming learning objectives. } \\
\text { - Using teaching aids. } \\
\text { - Using teaching methods. } \\
\text { - Organizing the board. } \\
\text { - Applying warm-up /closure techniques. } \\
\text { - Managing the classroom. }\end{array}$ \\
\hline Two & $\begin{array}{l}\text { Expected } \\
\text { Challenges }\end{array}$ & $\begin{array}{l}\text {-Participants considered teaching a difficult job. They } \\
\text { referred to it as the profession of challenges and } \\
\text { responsibilities } \\
\text {-The most common problems they see expected: } \\
\text { managing the classroom, dealing with disruptive } \\
\text { students, and motivating passive students. }\end{array}$ \\
\hline Three & $\begin{array}{l}\text { Ways of } \\
\text { Overcoming } \\
\text { Problems }\end{array}$ & $\begin{array}{l}\text {-Participants suggested the following techniques to } \\
\text { achieve effective learning and deal with disruption, } \\
\text { management, and motivation issues: } \\
\text { - Talking to the student about good and bad } \\
\text { behavior (i.e., defining acceptable and } \\
\text { unacceptable behavior.) } \\
\text { - Referring to a punishment protocol: Making an } \\
\text { eye contact with the student reflecting un- } \\
\text { satisfaction with their behavior, moving the } \\
\text { student from his/her seat, assessing the role of } \\
\text { students discipline in evaluation, so } \\
\text { misbehaving causes mark decrease, giving } \\
\text { extra tasks and also extra homework, and } \\
\text { applying punishment through response-cost, } \\
\text { i.e. a student has rewards, privileges, or other } \\
\text { positive reinforcers taken away whenever he } \\
\text { /she engages in a problem behavior. } \\
\text { Using verbal and nonverbal reinforcements } \\
\text { according to the situation. }\end{array}$ \\
\hline
\end{tabular}

\subsection{Discussion}

From the assessment rubric results, it is clear that there is an increase in pre-service teachers' professional awareness. In their first report, they were unable to discuss comprehensively the roles and responsibilities of teaching. 
They lack perception, knowledge, and awareness regarding the profession. While in the second report, after the administration of the treatment, they became aware of the responsibilities and challenges of the profession. Also from the result of the interview, it is clear from the participants' responses that they gained awareness regarding the teaching profession. They are not only capable of discussing professional topics, but also presenting personal opinions and further suggestions.

The topics presented and the procedures followed during the administration of the treatment helped participants form their own perception about teaching. They were new comers to the Faculty of Education; they did not have a cognitive background about teaching responsibilities, roles, challenges, and skills. Moreover, due to their lack of perception, they were less motivated to attend methodological courses as well as academic ones. Therefore, in the present treatment it was a priority to present pivotal topics that any teacher cannot practice teaching without. Still, in an interesting way that guarantee the attention, interest, and interaction of the participant.

Thus, by using a multimodal education in teaching a methodological course, the researcher increased pre-service teachers' awareness about the teaching profession. This awareness was clear from the change in their perception, attitude, and also participation during the lectures. This change is supposed to affect early teaching performance during practicum in the third year and reduce the gap between theory and practice. The following figure summarizes the effect of the multimodal education on professional awareness:

Figure3. Multimodal Education and Professional Awareness 
مجلة دراسات في المناهج وطرق التّريس، الترقيم الدولي (ISSN 2535-213X)/ العدد 245 (2019م)

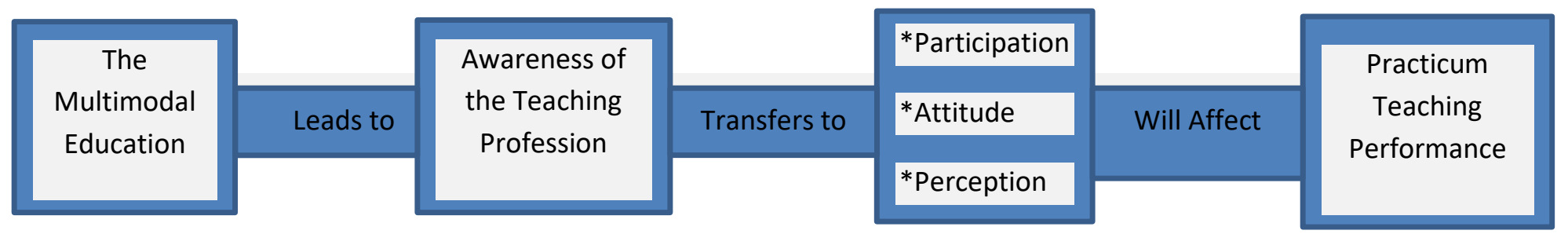

(Source: Original)

The researcher in this study focused on the following points: First, choosing first year pre-service teachers who lack awareness and perception about teaching to be the study sample. They are expected to progress better if they receive an early professional preparation. Also, they are expected to be motivated if the course theoretical background is introduced in an interesting way that relates theory to practice. It is worth mentioning that the researcher taught the same course content to first year pre-service teachers in previous years and the results were not satisfying. Second, investigating the use of a new independent variable that is considered according to many previously mentioned researchers an educational trend. Third, integrating technology with class discussions as it has a positive influence on the participants' motivation and learning.

The result of the study coincides with the findings of Mostafa (2005); Hamadtoh (2007); Abdel-Halim (2008); and El-Bassuony (2011). The present study and the aforementioned proved to be effective in developing professionalism of pre-service teachers. The differences are: in the present study the focus was on professional awareness in particular, the sample was first year students not third or fourth year as the majority of these studies, and the treatment was an education based on multimodality, the educational trend 
that proved to be effective in achieving the purpose of the study. This coincides with the results of Ajayi (2009), Guichon and McLornan (2008), Wang (2015), and Papageorgiou and Lameras (2017) that also found multimodality highly effective in achieving the educational purposes in concern.

\section{Conclusions, Recommendations, and Suggestions for Further Research}

\subsection{Conclusions}

The results of the present study indicated that a multimodal education which combined network resources, handouts, and class discussion was effective in developing the participants' awareness of the teaching profession. Moreover, the researcher noticed that a multimodality-based treatment had benefits such as considering different learning styles, developing cognitive skills, increasing motivation, and improving various professional skills. Thus, the present study could provide the basis for many other treatments based on multimodal education to develop different skills in the EFL context.

\subsection{Recommendations}

In the light of the findings of the present study, the researcher recommends the following:

- EFL pre-service teachers' preparation program should adopt new trends such as the application of multimedia and network resources in multimodal classes. 
- Faculty of Education recently joined students should receive competent professional preparation that increases their awareness and perception of the teaching profession, paving the way for a better performance later in the practicum applied in the third year.

- Pre-service teachers' needs should be the basis for designing methodology courses.

- All classrooms in Faculties of Education should be provided with a network connection and a data show to facilitate the application of various technology-supported classes.

- Faculties of Education staff members who hold meetings with new student-teachers should accept only highly motivated to be teachers candidates as teaching is not an ordinary career; it is the profession of challenges and creativity.

\subsection{Suggestions for Further Research}

Based on the study results, the researcher presented the following suggestions:

- More studies testing multimodality's effectiveness for teachers' preparation are needed including other professional skills and carried on a larger scale of pre-service teachers.

- More research that investigates student-teachers' needs is required so as to consider these needs in designing methodology courses.

- Studies that use different up-to-date treatments, other than multimodal education, to develop pre-service teachers' professionalism are needed. The researcher suggests new treatments based on: flipped classrooms, 
micro lessons, micro videos, chat groups, action research, strategic questioning, and scenario educational software (SES).

\section{References}

Abdel-Halim, S. (2008). The Effect of Using Some Professional Development Strategies on Improving the Teaching Performance of English Language Student Teacher at the Faculty of Education, Helwan University in the light of Pre- Service Teacher Standards. Published Doctoral Dissertation, Faculty of Education, Helwan University.

Ajayi, L. (2008). Meaning-making, Multimodal Representation, and Transformative Pedagogy: An Exploration of Meaning Construction Instructional Practices in an ESL High School Classroom. Journal of Language, Identity \& Education, 7(3-4), 206-229.

Ajayi, L. (2009). English as a Second Language Learners' Exploration of Multimodal Texts in a Junior High School. Journal of Adolescent \& Adult Literacy, 52(7), 585-595.

Andrews, S. (2007). Teacher Language Awareness. Cambridge: Cambridge University Press.

Badawi, M. (2009). Using Blended Learning for Enhancing EFL Prospective Teachers'Pedagogical Knowledge and Performance. (ERIC Document Reproduction Service No. ED504993)

Borg, S. (2001). Self-perception and Practice in Teaching Grammar. ELT Journal, 55(1), 21-29. 
Borg, S. (2003). Teacher Cognition in Language Teaching: A Review of Research on What Language Teachers Think, Know, Believe, and Do. Language Teaching Research, 36(1), 81-109.

Borg, S. (2009). Introducing Language Teacher Cognition. Retrieved August 12, 2018 from: http://www.education.leeds.ac.uk.

Bransford, J., Brown, A., \& Cocking, R. (2000). How people learn: Brain, Mind, Experience, and School. Washington, D. C.: National Academy Press.

Çakıcı, D. (2018). Metacognitive Awareness and Critical Thinking Abilities of Pre-service EFL Teachers. Journal of Education and Learning, 7(5),116129.

Castaneda-Trujillo, J., \& Aguirre-Hernández, A. (2018). Pre-service English Teachers' Voices about Teaching Practicum. HOW, 25(1), 156-173.

Cope, B. \& Kalantzis, M. (2009). Multiliteracies: New literacies, new learning. Pedagogies: An international journal, 4(3), 164-195.

Diab , A., Abdel-Haq, E., and Aly, M. (2018). The Effectiveness of Using Content and Language Integrated Learning (CLIL) Approach to Enhance EFL Student Teachers' Cultural Awareness. (ERIC Document Reproduction Service No. ED582276).

Egbert, J., \& Salsbury, T. (2009). "Out of Complacency and into Action”: An Exploration of Professional Development Experiences in School/Home Literacy Engagement. Teaching Education, 20(4), 375-393. 
El-Bassuony, J. (2011). Using Collaborative Action Research and Facebook to Develop EFL Pre-service Teachers' Professionalism in the Light of STEPS Standards. Studies in Curriculum and Instruction, 176, 1-48.

Freeman, D. (2001). Second Language Teacher Education. In D. Nunan \& R. Carter (Eds.), The Cambridge Guide to Teaching English to Speakers of Other Languages (pp. 72-79). Cambridge, UK: Cambridge University Press.

Guichon, N. \& S. McLornan (2008). The Effects of Multimodality on L2 Learners: Implications for CALL Resource Design, System,36.

Hamad, A. (1999). The Concept of Competent in the Second Language Teacher Preparation. Quarter National Commission for Education Culture \& Science, 129.

Hamadtoh, R. (2007). A proposed Training Program Based on the Contemporary World Standards for Developing Some EFL Teaching Skills for the Student Teachers at the College of Education. Unpublished Master's Thesis, Faculty of Education, Mansoura University.

Jewitt, C. (2008). Multimodality and Literacy in School Classrooms. Review of Research in Education, 32(1), 241-267.

Jewitt, C. (2013). Multimodal Methods for Researching Digital Technologies. In: The Sage handbook of digital technology research. Los Angeles: SAGE, 250-265. 
Kaymakamoğlu, S. (2019). In Search of Developing Practical Knowledge in Pre-service EFL Teachers: A Proposed Model. Journal ofLanguage and Linguistic Studies, 15(3), 1000-1010.

Kim, N. (2010). Multimodal ESL Instruction: Exploring New Teaching in an Adolescent English as a Second Language Classroom. Paper presented at the Annual Meeting of the American Educational Research Association, Denver, CO.

Kress, G. \& Van Leeuwen, T. (2001). Multimodal Discourse: The Modes and Media of Contemporary Communication, London: Arnold.

Kumaravadivelu, B. (2006). Understanding Language Teaching: From Method to Postmethod, New Jersey: Lawrence Erlbaum Associates.

Lucero, E. (2016). Reflections upon a Pedagogical Practice Experience: Standpoints, Definitions, and Knowledge. In R. M. Páez (Ed.), Práctica y experiencia: claves del saber pedagógico docente (pp. 143-168). Bogotá, CO: Ediciones Unisalle.

Mayer, R. (2001). Multimedia learning. New York: Cambridge University Press.

Mostafa, A. (1999). A proposed Professional Needs - Based Program for Preparing

Pre -service English Language Teacher in The Primary Education Branch. Unpublished Doctoral Dissertation, Faculty of Education, Mansoura University. 
Mostafa, A. (2005). Exploring Pre and In-service EFL Teachers' Prevalent Levels of Reflection and Their Relationship to Teaching Performance. CDELT Occasional Papers, 39.

Mills, K. (2010). A Review of the "Digital Turn" in the New Literacy Studies. Review of Educational Research, 80(2), 246-271.

New London Group (1996). A Pedagogy of Multiliteracies: Designing Social Futures, Harvard Educational Review, 66(1), 60-90.

OECD/UNESCO (2016). Education in Thailand: An OECD-UNESCO Perspective, Reviews of National Policies for Education. OECD Publishing, Paris.

Papageorgiou, V. \& Lameras, P. (2017). Multimodal Teaching and Learning with the Use of Technology: Meanings, Practices and Discourses. 14th International Conference on Cognition and Exploratory Learning in Digital Age (CELDA 2017). ISBN: 978-989-8533-68-5

Phipps, S., \& Borg, S. (2009). Exploring Tensions Between Teachers' Grammar Teaching Beliefs and Practices. System, 37(3), 380-390.

Russell, M., Bebell, D., O’Dwyer, L., \& O’Connor, K. (2003). Examining Teacher Technology Use: Implications for Preservice and Inservice Teacher Preparation. Journal of Teacher Education, 54(4), 297-310.

Salkovic, C. (2013). Multimodal Writing. Retrieved August 15, 2018 from https://cynthiasalkovicdk1420.wordpress.com . 
Sharples, M. et al. (2016). Innovating Pedagogy 2016: Open University Innovation Report 5, Milton Keynes: Open University .

Sherman, C. (2014). Transition Matters: Career Development Education. Retrieved September 10, 2018 from https://slideplayer.com.

Wang, C. (2012). Pre-service Teachers' Perceptions of Learning a Foreign Language Online: Preparing Teachers to Work with Linguistic, Cultural, and Technological Diversity. International Journal of Computer-Assisted Language Learning and Teaching, 2(2), 30-44.

Wang, C. (2015). From Preservice to Inservice: Can Practicing Foreign Language Learning Online Help Teachers Transfer Linguistic, Cultural, and Technological Awareness into Teaching English Language Learners? International Journal of Computer-Assisted Language Learning and Teaching, 5(2), 1-21.

Wang, Q. (2015). Study on the New Model of College English Teaching under the Setting of Multimodality. Universal Journal of Educational Research 3(8): 473-477. 